\title{
Addressing China's Growing Water Shortages and Associated Social and Environmental Consequences ${ }^{1}$
}

\author{
Zmarak Shalizi ${ }^{2}$ \\ Development Research Group, World Bank, \\ 1818 H St. N.W. Washington DC 20433, USA
}

\begin{abstract}
China has experienced transformation from an agricultural based economy to the manufacturing workshop of the world on a scale and rapidity that is unprecedented. The associated relocation of the population from relatively low density rural areas to very high density urban areas is having a significant impact on the quantity and quality of water available as inputs into the production and consumption process, as well as the ability of the water system to absorb and neutralize the waste byproducts deposited into it. Water shortages are most severe in the north of the country, where surface water diversion is excessive and groundwater is being depleted. In addition, the quality of water is deteriorating because of pollution, thereby aggravating existing water shortages.
\end{abstract}

The biggest challenge ahead will be for national and local governments to craft policies and rules within China's complex cultural and legal administrative system that provide incentives for users to increase efficiency of water use, and for polluters to clean up the water they use and return clean water to stream flows. Using a standard public economics framework, water requirements for public goods - such as ecosystem needs - should be set aside first, before allocating property rights in water (to enable water markets to function and generate efficient allocation signals). Even then, water markets will have to be regulated to ensure public goods, such as public health, are not compromised. Until water markets are implemented, staying the course on increasing water and wastewater prices administratively and encouraging water conservation are necessary to reduce the wasting of current scarce water resources, as well as the new water supplies to be provided in the future.

World Bank Policy Research Working Paper 3895, April 2006

The Policy Research Working Paper Series disseminates the findings of work in progress to encourage the exchange of ideas about development issues. An objective of the series is to get the findings out quickly, even if the presentations are less than fully polished. The papers carry the names of the authors and should be cited accordingly. The findings, interpretations, and conclusions expressed in this paper are entirely those of the authors. They do not necessarily represent the view of the World Bank, its Executive Directors, or the countries they represent. Policy Research Working Papers are available online at http://econ.worldbank.org.

\footnotetext{
${ }^{1}$ This paper was prepared as a background note for the World Bank Report by Yusuf, Shahid entitled, “China's Development Priorities” (forthcoming 2006). Comments on earlier draft were provided by Douglas C. Olson and Daniel Gunaratnam.

${ }^{2}$ I would like to acknowledge the substantial research assistance provided by Tomoko Okano.
} 
Table of Contents

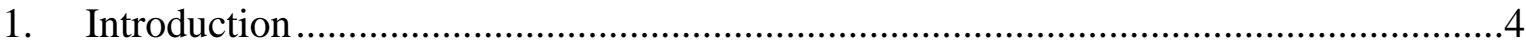

1.1.1 Per Capita Availability of Water is Low by International Standards: ..................4

1.1.2 Population Growth is Reducing "Per Capita Availability of Water": ..................4

1.1.3 China Will Soon Become the Most Water Stressed Country in East and

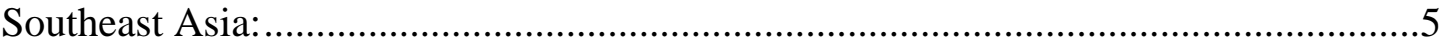

2. Trends in Water Availability / Supply is Manifested Most Clearly in Spatial Terms ...7

2.1 Water Quantity -- is inadequate: ........................................................................

2.1.1 Water Shortages are Most Acute in the North: ................................................7

2.1.2 Surface Water Diversion is Excessive -- Resulting in Inadequate Water Flows to

Flush Channels and Supply Downstream Needs: .....................................................9

2.1.3 Groundwater is Being Depleted - Causing Land Subsidence in Cities and

Saltwater Intrusion Along the Coast: ....................................................................9

2.1.4 Water Shortage are Also Emerging in Rapidly Growing Urban Sub-regions in

Other Parts of China - Both North and South: .........................................................10

2.2 Quality of Water -- is deteriorating because of pollution, thereby aggravating

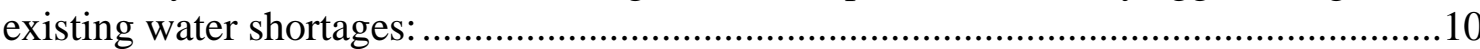

2.2.1 Sources of Pollution - Are Currently Evenly Divided Between Rural and Urban

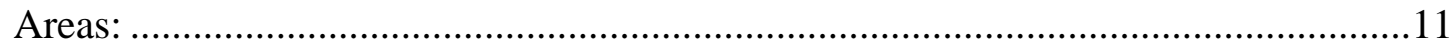

2.2.2 Types of Pollution -- Wastewater Discharge by Municipalities is Growing

Relative to Industries, but Toxic Loads are Undocumented .....................................12

3. The Trends in Water Demand are Best Illustrated Sectorally....................................13

3.1 Water Demand for Production purposes - by Farms and Factories: ........................13

3.2 Water Demand for Consumption purposes - by Households: ..................................14

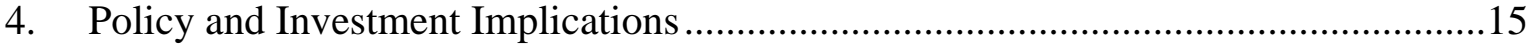

4.1. Trends Affecting Future Demand Projections: ...............................................17

4.1.1 Elasticity of Water Demand with Respect to GDP: .....................................17

4.1.2 Long-term water use trends:.........................................................................18

4.1.3 In the Scenarios Above the Real Pressure on Water Demand Emanates from

Lack of Efficiency Improvements in Water Use in Agriculture and Industry:............20

4.2 The Utility of Prices as a Signaling Device can be Increased if Markets to Trade

Water Rights can be Implemented with Appropriate Safeguards /Complementary

Actions to Address Public Goods: ............................................................................20

4.2.1 Addressing the Social Implications of Increasing the Role of Water Pricing: ...23

4.2.2 Addressing the Environmental Implications of Increasing the Role of Water

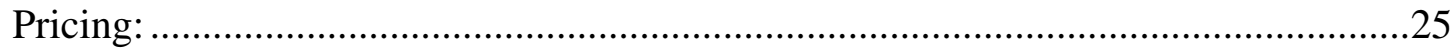

4.3 Reducing the Cost of Wastewater Treatment and Improving it's Monitoring: .........25

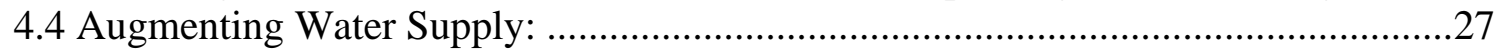

4.5 There is a Clear Coordination Function that Requires Addressing Institutional Issues

if Policies and Programs are to be Implemented Within a Reasonable Budget and Time

Frame:

4.6 A Broader and More Detailed Analysis of Socio-economic Options is Needed to

Complement the Comprehensive 2002 Study on Technical Water Options for China: ..30

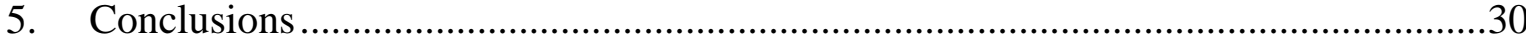

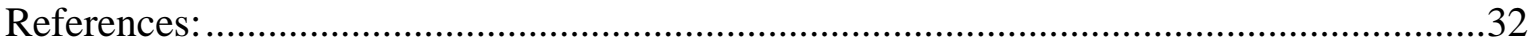




\section{Introduction}

The objective of this paper is to provide a brief overview of the issues and options for addressing water problems in China. It is organized in five sections. Section 1 briefly introduces the growing water scarcity in China. Section 2 describes trends in water supply and notes that these are best understood in spatial terms. Section 3 describes trends in water demand and notes that these are best understood in sectoral terms. Section 4 discusses policy and investment implications, and section 5 concludes.

\subsubsection{Per Capita Availability of Water Is Low by International Standards}

China's total naturally available water flows (not stocks) from all surface and underground sources is estimated at approximately 2,812 billion $\mathrm{m}^{3}$ (BCM) per annum, and ranked sixth in the world behind Brazil, Russia, Canada, Indonesia, and the U.S. ${ }^{3}$. However, on a per capita basis China's naturally available water flow per annum of 2,206 m³/person in 2004 is one of the lowest levels in the world for a populous country (next to India's at 1,754 $\mathrm{m}^{3} /$ person $)^{4}$. China's per capita naturally available water per annum is one-third of the average of the developing countries (7,762 $\mathrm{m}^{3} /$ person), one-fourth of the world average $\left(8,549 \mathrm{~m}^{3} /\right.$ person), and almost one-fifth of the U.S. average $\left(10,332 \mathrm{~m}^{3} / \text { person }\right)^{5}$. So in a global context China's per capita availability of water is exceedingly low, suggesting the potential for water stress as demand for usable water rises with growth in population and in per capita incomes.

\subsubsection{Population Growth Is Reducing “Per Capita Availability of Water”}

For analytic purposes, the natural supply of water in China can be assumed constant (barring major climatic changes and retreat of glaciers, major desalinization programs, or major transfers of water from neighboring countries). By contrast, despite the one child policy, China's population has been growing steadily from about one billion in 1980 to 1.19 billion in 1993 and 1.29 billion in 2003 (Table 1.1).

Table 1.1 China: Population

\begin{tabular}{|c|c|c|c|c|c|c|c|c|c|}
\hline & \multicolumn{6}{|c|}{ Population } & \multicolumn{3}{|c|}{ Growth Rate } \\
\hline & \multicolumn{2}{|c|}{1980} & \multicolumn{2}{|c|}{1993} & \multicolumn{2}{|c|}{2003} & $80-93$ & $93-03$ & $80-03$ \\
\hline & billion & $\%$ & billion & $\%$ & billion & $\%$ & $\%$ & $\%$ & $\%$ \\
\hline TOTAL & 0.99 & 100 & 1.19 & 100 & 1.29 & 100 & 1.3 & 0.8 & 1.1 \\
\hline North & 0.42 & 43 & 0.48 & 41 & 0.54 & 42 & 1.0 & 1.0 & 1.1 \\
\hline South & 0.58 & 58 & 0.66 & 55 & 0.75 & 58 & 0.9 & 1.2 & 1.1 \\
\hline Urban & 0.19 & 19 & 0.33 & 28 & 0.52 & 40 & 4.0 & 4.2 & 4.3 \\
\hline Rural & 0.80 & 81 & 0.85 & 72 & 0.77 & 60 & 0.5 & -0.9 & -0.1 \\
\hline
\end{tabular}

Source: Chinese Statistical Yearbook 1991, 2004

\footnotetext{
${ }^{3}$ Food and Agricultural Organization (FAO) AQUASTAT database (World Resources Institute) and USDA.

${ }^{4}$ USDA. 2000. P.25.

${ }^{5}$ FAO AQUASTAT (World Resources Institute)
} 
As a result, China's annual p.c. water availability has dropped by $23 \%$ in the last two decades (from 2,849 m³/person in 1980 to 2,180 m³/person in 2003).

\subsubsection{China Will Soon Become the Most Water Stressed Country in East and Southeast Asia}

There are a number of definitions commonly used in the literature, to describe water stresses and shortages. The International Water Management Institute (IWMI) uses a fourpart scale to classify countries in terms of their overall water use. A) Low exploitation: $<20 \%$; B) Comfortable range: 20-59\%; C) Environmentally overexploited: 60-100\%; D) Mining: $>100 \%{ }^{6}$. The denominator in the ratio includes naturally available flows of water (i.e. all surface and underground water flows) based on annual precipitation in a jurisdiction. But it excludes stocks/reserves (in dams, as well as, surface and underground lakes), which can be used to buffer periodic climatic shocks. The ratio can exceed 100\% when the latter are drawn down routinely for normal use rather than to cope with shocks. The numerator in the ratio includes the average amount of water used for all human activities (production and consumption - including amenities), plus water needs of the ecosystem (estimated to range between $25-40 \%$ of normal flows of surface and underground water).

The UNDP, UNEP, World Bank and the World Resources Institute define "water stress" on a per capita basis as annual water availability of $2,000 \mathrm{~m}^{3} /$ person or less. In this framework "water scarcity" is defined as $1,000 \mathrm{~m}^{3} /$ person $^{7}$ or less. The water consumed per person (from all sources - surface and aquifer) includes not only what is normally classified as domestic/residential water consumption per capita, but also the individual's share of national water consumed for productive activities - agriculture and industry - and the individual's share of water required for ecosystem needs (flushing channels, supporting aquatic life, etc.).

Using the per capita definition (of the UNDP, UNEP, World Bank, WRI) China as a whole will be classified as water stressed by 2010 at the current rate of population growth. Using the IWMI's classification, China currently uses $44 \%$ of its water and is still within the "comfortable" water use margin, but its use of water is projected to exceed $60 \%$ by $2020^{8}$, putting it in the "environmentally overexploited" category. Thus, by either definition, China will face a potentially serious water management problem in the coming decades.

The water use percentages cited above are substantially higher than the ratio of what is recorded as "Water Use"9 in Chinese statistics relative to the total natural availability of water -- currently on the order of $20 \%$ (see Table 1.2).

\footnotetext{
${ }^{6}$ WDR 2003a. p.87.

${ }^{7}$ There are other definitions, e.g. by Dr. Malin Falkenmark, who defines water stress as $1,700 \mathrm{~m}^{3}$ per person and water scarcity as 1,000 $\mathrm{m}^{3}$ per person (Robert 1993). Economy. 2004. p 287 and WDR 2003. p.48.

${ }^{8}$ International Water Management Institute (IWMI), cited in WDR 2003a. p.87.

${ }^{9}$ Water Use is akin to Aggregate Demand and defined as the sum of demand for water in production $<$ agriculture plus industry $>$ and in consumption < rural plus urban households $>$ and is discussed in more detail in a later section.
} 
Table 1.2 China Water: Availability and Use

\begin{tabular}{|c|c|c|c|c|c|c|c|c|}
\hline & \multirow{2}{*}{\multicolumn{2}{|c|}{$\begin{array}{l}\text { Water Availability* } \\
\text { (gross) }\end{array}$}} & \multicolumn{6}{|c|}{ Water Use (\%: relative to Water Availability) } \\
\hline & & & \multicolumn{2}{|c|}{1980} & \multicolumn{2}{|c|}{1993} & \multicolumn{2}{|c|}{2000} \\
\hline & $\mathrm{BCM}$ & $\%$ & $\mathrm{BCM}$ & $\%$ & $\mathrm{BCM}$ & $\%$ & $\mathrm{BCM}$ & $\%$ \\
\hline TOTAL & 2,812 & 100 & 444 & 16 & 519 & 18 & 550 & 20 \\
\hline Surface & 2,712 & 96 & & & & & & \\
\hline Aquifer & 829 & 29 & & & & & & \\
\hline North & 405 & 14 & 163 & 40 & 188 & 46 & 196 & 48 \\
\hline Surface & 334 & 12 & & & & & & \\
\hline Aquifer & 168 & 6 & & & & & & \\
\hline South & 2,406 & 86 & 281 & 12 & 330 & 14 & 354 & 15 \\
\hline Surface & 2,376 & 84 & & & & & & \\
\hline Aquifer & 659 & 23 & & & & & & \\
\hline
\end{tabular}

* The sum of surface and aquifer water exceeds the total water resources by the amount of overlap between them

Source: Chinese Statistical Yearbook 1991, 2003 and ESCAP (Annex 2)

The latter figure superficially suggests that there is substantial scope for expanding water use in China. However, such a conclusion is not warranted because:

- The aggregate use figures refer only to flows tapped for human use and do not include flows required for ecosystem maintenance.

- The data on gross availability exceeds the amount of water that actually can be harnessed for human use (i.e. in a "cost-effective" way based on "known"/current technologies). The latter figure is not published even if it is known. Without it, it is difficult to meaningfully analyze the scope for expanding supply nationwide (whether provided through public or private suppliers, or on own account) relative to the growing demand for water.

- The spatial distribution of water supply and demand are quite different, and costly to overcome. At the sub-national level there are already areas exhibiting not just "water stress", but the more adverse condition of "water scarcity". 


\section{Trends in Water Availability / Supply Is Manifested Most Clearly in Spatial Terms}

\subsection{Water Quantity -- Is Inadequate}

\subsubsection{Water Shortages Are Most Acute in the North}

China's low natural availability of water per person of 2,180 $\mathrm{m}^{3}$ in 2003 masks substantial regional disparities in water availability ${ }^{10}$. Demand for water is growing throughout the country -- but availability in the north is about a quarter that in the south -- $757 \mathrm{~m}^{3} /$ person vs. 3,208 $\mathrm{m}^{3} /$ person respectively (see Table 2.1 ) -- and a tenth of the world average ${ }^{11}$. The $757 \mathrm{~m}^{3}$ /person in the North in 2003 qualifies the North as a whole as an area of 'water scarcity', which is a condition worse than 'water stress'. Yet the North is a very large area. It is home to roughly 42\% of China's population in 2003 -- 538 million people (greater than the total population in Europe or in Latin America) -- with access to only 14\% of China's water resources (Table 2.1).

Table 2.1 China: Water Availability per Capita

\begin{tabular}{|c|c|c|c|c|c|c|c|c|}
\hline & \multicolumn{2}{|c|}{$\begin{array}{l}\text { Water Availability* } \\
\text { (gross) }\end{array}$} & \multicolumn{3}{|c|}{$\begin{array}{l}\text { Population } \\
\text { (billion) }\end{array}$} & \multicolumn{3}{|c|}{$\begin{array}{c}\text { Water Availability per capita } \\
\left(\mathrm{m}^{3}\right)\end{array}$} \\
\hline & $\mathrm{BCM}$ & $\%$ & 1980 & 1993 & 2003 & 1980 & 1993 & 2003 \\
\hline TOTAL & 2,812 & 100 & 0.99 & 1.19 & 1.29 & 2,849 & 2,373 & 2,180 \\
\hline Surface & 2,712 & 96 & & & & & & \\
\hline Aquifer & 829 & 29 & & & & & & \\
\hline North & 405 & 14 & 0.42 & 0.48 & 0.54 & 964 & 838 & 757 \\
\hline Surface & 334 & 12 & & & & & & \\
\hline Aquifer & 168 & 6 & & & & & & \\
\hline South & 2,406 & 86 & 0.58 & 0.66 & 0.75 & 4,176 & 3,665 & 3,208 \\
\hline Surface & 2,376 & 84 & & & & & & \\
\hline Aquifer & 659 & 23 & & & & & & \\
\hline
\end{tabular}

* The sum of surface and aquifer water exceeds the total water resources by the amount of overlap between them Source: Chinese Statistical Yearbook 1991, 2003 and ESCAP (Annex 2)

\footnotetext{
${ }^{10}$ Average rainfall is approximately nine times more in the southeast $(1,800 \mathrm{~mm})$ than in the northwest (200 $\mathrm{mm}$ ), and over $45 \%$ of China receives less than $400 \mathrm{~mm}$ precipitation a year. Economy. 2004. p.68.

${ }^{11}$ Wang and Somik. 2002. p.759.
} 
Table 2.2 shows the gross renewable water resources available in each of the nine major externally draining river basins in China. As shown, generally surface runoff dominates underground water flows in all the basins. But in the North water use relative to availability is often three to four times as high as in the South -- -- in the Hai river basin it is in excess of $95 \%$.

Table 2.2 China: Water Availability and Human Use

\begin{tabular}{|c|c|c|c|c|c|c|c|}
\hline & \multirow{2}{*}{$\begin{array}{c}\begin{array}{c}\text { Availability } \\
\text { (gross) }\end{array} \\
\text { BCM }\end{array}$} & \multicolumn{3}{|c|}{$\begin{array}{l}\text { Water Use } \\
\text { (BCM) }\end{array}$} & \multicolumn{3}{|c|}{$\begin{array}{c}\text { Water Use Relative to } \\
\text { gross Availability } \\
(\%)\end{array}$} \\
\hline & & 1980 & 1993 & 2000 & 1980 & 1993 & 2000 \\
\hline TOTAL & 2,812 & 444 & 519 & 550 & 16 & 18 & 20 \\
\hline North & 405 & 163 & 188 & 197 & 40 & 46 & 49 \\
\hline Surface & 334 & 114 & & & 34 & & \\
\hline Aquifer & 168 & 50 & & & 30 & & \\
\hline Song-Liao & 193 & 35 & 50 & 57 & 18 & 26 & 30 \\
\hline Surface & 165 & 29 & & & 17 & & \\
\hline Aquifer & 62 & 9 & & & 14 & & \\
\hline Hai-Luan & 42 & 38 & 41 & 40 & 91 & 98 & 95 \\
\hline Surface & 29 & 18 & & & 62 & & \\
\hline Aquifer & 26 & 20 & & & 78 & & \\
\hline Huai & 96 & 53 & 57 & 61 & 55 & 59 & 64 \\
\hline Surface & 74 & 40 & & & 54 & & \\
\hline Aquifer & 39 & 13 & & & 33 & & \\
\hline Huang & 74 & 36 & 40 & 39 & 48 & 54 & 53 \\
\hline Surface & 66 & 27 & & & 42 & & \\
\hline Aquifer & 41 & 8 & & & 20 & & \\
\hline South & 2,406 & 281 & 330 & 352 & 12 & 14 & 15 \\
\hline Surface & 2,376 & 269 & & & 11 & & \\
\hline Aquifer & 659 & 17 & & & 3 & & \\
\hline Chang & 961 & 135 & 164 & 168 & 14 & 17 & 17 \\
\hline Surface & 951 & 129 & & & 14 & & \\
\hline Aquifer & 246 & 7 & & & 3 & & \\
\hline Zhu & 471 & 66 & 73 & 85 & 14 & 15 & 18 \\
\hline Surface & 468 & 66 & & & 14 & & \\
\hline Aquifer & 112 & 1 & & & 1 & & \\
\hline Southeast & 259 & 19 & 29 & 31 & 7 & 11 & 12 \\
\hline Surface & 256 & 19 & & & 7 & & \\
\hline Aquifer & 61 & 1 & & & 1 & & \\
\hline Southwest & 585 & 4 & 6 & 10 & 1 & 1 & 2 \\
\hline Surface & 585 & 4 & & & 1 & & \\
\hline Aquifer & 154 & 0 & & & 0 & & \\
\hline Interior Basins & 130 & 56 & 58 & 58 & 43 & 45 & 45 \\
\hline Surface & 116 & 52 & & & 45 & & \\
\hline Aquifer & 86 & 9 & & & 10 & & \\
\hline
\end{tabular}

* The sum of surface and aquifer water exceeds the total water resources by the amount of overlap be Source: Chinese Statistical Yearbook 1991, 2003 (Annex 2) 


\subsubsection{Surface Water Diversion Is Excessive -- Resulting in Inadequate Water Flows to Flush Channels and Supply Downstream Needs}

Water scarcity is most acute north of the Yangtze River, particularly in the catchments of the Huai, Hai ${ }^{12}$, and Huang (Yellow) Rivers ${ }^{13}$. Since the 1980s, water shortages have been growing in magnitude and frequency of occurrence for urban industry, domestic consumption, and irrigated agriculture, creating severe economic losses. Total water shortages in 2000 were calculated at 38.8 billion $\mathrm{m}^{3}$ and projected to be 56.5 billion $\mathrm{m}^{3}$ by 2050 unless measures are taken to reduce demands and to augment supplies. These shortages were estimated to cost the Chinese economy between 5 billion Yuan and 8.7 billion Yuan p.a. (USD 620 million and USD 1.06 billion) ${ }^{14}$. However, as will be noted in the section on policy and investment implication these types of calculations can be misleading as they presume that the water deficit can be fully closed by augmenting water supply at reasonable cost which is not the case.

The Yellow River Basin drains an area of almost $800,000 \mathrm{~km}^{2}$, and serves a population of over 100 million, with an annual flow of $707 \mathrm{~m}^{3} /$ person. The water utilization rate in the Yellow River is about $90 \%$ of the available water - which is close to complete water resources exploitation - creating severe problems for people and nature ${ }^{15}$. "The Yellow River -- the World's fourth largest river -- once referred to as "China's sorrow" because its high waters caused so much destruction, has been running dry in places since 1985"16. A study in 2001 noted that "in recent years the water flows at the deltas of the Hai and Yellow rivers have averaged about 15 billion $\mathrm{m}^{3}$ less than the amount required to transport silt and to maintain estuarine and coastal environments" 17 and that the duration of low flow periods in the river has increased from forty days in early 1990s to two hundred days in 1997. Another study suggests that "reserving even a bare minimum of $25 \%$ of the total flow of the Yellow River for the environment brings the basin to the level of absolute water scarcity" ${ }^{\prime}$.

\subsubsection{Groundwater Is Being Depleted - Causing Land Subsidence in Cities and Saltwater Intrusion along the Coast}

To compensate for surface water scarcity there is growing reliance on groundwater in the North. Groundwater is being depleted at a faster rate than it is being replenished - leading to "mining" of aquifers. When aquifers are "mined" they are not available as an insurance in drought periods, thereby compromising sustainable use of the resource for current, as well as, future generations. In some areas, the destruction of aquifers is contributing to drought and dust storms and creating urban refugees from fragile lands.

\footnotetext{
${ }^{12}$ In the densely populated Hai river basin, for example, industrial output is growing rapidly, and the basin is intensively cultivated. However, water availability per capita is only $343 \mathrm{~m}^{3}$ per year, in contrast to residents in the Pearl River basin in the wet area of China who have 9 times more water available per capita.

${ }^{13}$ So called $3 \mathrm{H}$ rivers.

${ }^{14}$ Economy. "The Case of China” 1997. These numbers were calculated for all China as of 1997.

${ }^{15}$ WRI Research Report 2. p.17.

${ }^{16}$ Economy. 2004. p.69.

${ }^{17}$ World Bank. 2002b

${ }^{18}$ WRI Research Report 2. P.17.
} 
The extent of the "mining" of groundwater is quite severe (e.g. sustainable groundwater flows in the Hai Basin have been estimated to be on the order of 17.3 billion $\mathrm{m}^{3}$ per annum while 1998 withdrawals were 26.1 billion $\mathrm{m}^{3}$ per annum) -- indicating an over-extraction as high as 8.8 billion $\mathrm{m}^{3}$ annually. As a result, groundwater tables have dropped up to 90 meters in the Hai plains ${ }^{19}$. In Beijing it is estimated that groundwater tables have dropped by 100-300 meters (anecdotal evidence suggests that some deep wells around Beijing now have to reach $1000 \mathrm{~m}$ to tap fresh water increasing dramatically the cost of supply).

The removal of underground water domes has many different adverse consequences. It has resulted in salt-water intrusion along coastal provinces, by one-estimate 72 locations covering an area of $142 \mathrm{~km}^{2}$. It is also leading to subsidence in coastal and non-coastal areas. The subsidence is large, up to several meters in cities like Beijing, Tianjin, Taiyuan, Shijiazhuang, and Shanghai, causing damage to buildings and bridges, and even their collapse (one estimate is Y 1.14 billion Yuan in damage to structures in 1985). Subsidence is also lowering flood protection and exacerbating water logging in urban areas because drainage is less effective ${ }^{20}$.

\subsubsection{Water Shortages Are Also Emerging in Rapidly Growing Urban Sub- regions in Other Parts of China - Both North and South}

While the problems in Beijing, and the Hai river basin are well known, they are not unique. In the relatively dry regions in the North, Northwest and Northeast there are many large urban centers, including seven cities with populations in excess of 2 million people each, and 81 cities with populations of 200,000-500,000 people each. In many of the major cities urban water use has also increased as mayors have embarked on beautification campaigns to plant trees, shrubs, flower, and grass along roadways and in municipal parks ${ }^{21}$, in part to attract new investments and higher skilled labor and in part to combat locally the effects of dust storms associated with surface and aquifer water depletion elsewhere. These large Chinese cities continue to compete with agriculture for scarce water resources. The problems are emerging in acute forms in other metropolitan sub-regions with very fast growth. It is estimated that more than 400 of China's 600 cities are short of water and about 100 face serious water shortage problems ${ }^{22}$.

\subsection{Quality of Water -- Is Deteriorating Because of Pollution, Thereby Aggravating Existing Water Shortages}

Currently, most of the water bodies in China are polluted and some are heavily polluted. Surface and groundwater pollution now represents a very large problem both for public health and the environment. Pollution degraded water (quality) exacerbates the shortage (quantity) of water resources available downstream. It also makes it difficult to recycle water where it is scarce. As such pollution represents a growing constraint on national development objectives.

\footnotetext{
${ }^{19}$ World Bank 2002b. P.2.

${ }^{20}$ World Bank 2002b. P.2.

${ }^{21}$ USDA. 2000. P.26.

${ }^{22}$ Wang and Somik. 2002. P.760. (Singer 1990)
} 
In 2003, 38.1\% of China's river waters overall were considered to be polluted, (up from 33\% a decade earlier). According to The State Environmental Protection Administration's (SEPA) annual report ${ }^{23}$, over $70 \%$ of the water in five of the seven major river systems the Huai, Songhua, Hai, Yellow, and Liao - was grade IV or worse i.e. it could not meet any designated beneficial uses. For Hai and Huai it was 80\%. Even the majestic Yangtze suffered a deep decline in water quality, more than doubling the percentage of its water not suitable for human contact to $48.5 \%$ in $2002^{24}$.

\subsubsection{Sources of Pollution - Are Currently Evenly Divided Between Rural and Urban Areas}

Overall, 50\% of water pollution is caused by non-point sources (in rural areas), including nutrient runoff, pesticides, and emissions from intensive livestock production, and the remaining $50 \%$ by industrial and municipal wastewater discharges and the leaching of solid waste 25 .

Rural: Non-point sources of water pollution include (i) fertilizer runoff, (ii) pesticide runoff, and (iii) discharges from intensive animal production enterprises. They are serious problems, especially in certain rural areas, and can be expected to increase in the immediate future.

(i) Nutrient runoff causes eutrophication, which is occurring in many lakes throughout China and also in near-shore marine areas that are shallow and/or experience limited tidal flushing. For example, about $70 \%$ of nutrient inflow into Lake Chao and Lake Dian is derived from agricultural runoff. China is now the biggest pesticide producer and consumer in the world. In 1999, 625,000 tons pesticides were produced domestically and 1.32 million tons pesticides were consumed ${ }^{26}$.

(ii) Most domestically produced insecticides and pesticides are classified as "high-toxicity, high-residue chemicals.” Two of the three top insecticides produced in 1996 were WHO Class 1 chemicals. Pesticide residues in crops and adverse impacts on biodiversity are a result of killing insects on an indiscriminate basis. These effects are highly visible especially in wealthier, high growth areas in China ${ }^{27}$.

(iii) Livestock production has increased its contribution to Gross Value of Agricultural Output from $14 \%$ in 1970 to $31 \%$ in 1998. This trend is expected to continue in the foreseeable future as urbanization increases, disposable incomes increase, and food distribution systems in rural areas improve. Within the livestock sector, pork production is of major importance accounting for $70 \%$ of all meat produced in China and $50 \%$ of pork

\footnotetext{
${ }^{23}$ Energy Information Administration (EAI) 2003. "Country Analysis Briefs” (SEPA State of the Environment in China 2003.)

${ }^{24}$ Economy. 2004. P.69.

${ }^{25}$ World Bank 2004.

${ }^{26}$ World Bank 2001b. p.49-51.

${ }^{27}$ World Bank 2001b. p. 59-61.
} 
production in the world. Amongst rural economic activities, family owned livestock operations are one of the most polluting ${ }^{28}$. Rural sources of pollution, such as livestock operations, rural industry and towns/villages remain essentially uncontrolled and unaccounted for by current government management programs ${ }^{29}$.

Urban: The rapid growth in urban populations and industrial activities has also been accompanied by a rapid rise in the level of pollution in China's waterways. In the absence of sufficient water treatment plants, large volumes of raw sewage are dumped daily into local streambeds, and industrial water is often untreated. When upstream water is returned to the stream polluted, water quality downstream is degraded. In some cases, polluted water in the streams has seeped into ground water ${ }^{30}$. Government monitoring and enforcement programs are having only limited impact for a number of reasons: selective application of the laws and weak enforcement at the local level; the absence of load based standards; and the setting of inappropriate standards that are not achievable given China's current level of technology and low level of fines.

"More than $75 \%$ of the water in rivers flowing through China's urban areas is unsuitable for drinking or fishing." "Only 6 of China's 27 largest cities' drinking water supply meet State standards. Many urban river sections and some large freshwater lakes are so polluted that they cannot even be used for irrigation"31.

\subsubsection{Types of Pollution -- Wastewater Discharge by Municipalities is Growing Relative to Industries, but Toxic Loads Are Undocumented}

In 2000, the major water pollutant -- COD discharge -- was almost evenly split between industrial and municipal sources, at approximately 7.4 million tons and 7.05 million tons respectively. Municipal wastewater and COD discharge has been growing relative to industrial wastewater discharge over time and by 2000, municipal wastewater discharge (at 22.1 billion tons) was $14 \%$ (or 2.7 billion tons) more than industrial wastewater discharge ${ }^{32}$. The costs of benefits foregone by not treating wastewater were estimated at 4 billion Yuan in 2000 rising to 23 billion Yuan in $2050^{33}$ in the Hai and Huai basins.

Municipal wastewater discharge is expected to grow in tandem with the growth in urban populations (if not in the growth in their per capita incomes). This rate was $3.1 \%$ in the 1990s, and is expected to be even larger over the next 10 to 20 years.

Disaggregating the total industrial discharge into sectors shows that six sectors (pulp/paper, food, chemicals, textiles, tanning, and mining) accounted for $87 \%$ of total industrial COD load but only $27 \%$ of gross industrial output value.

\footnotetext{
${ }^{28}$ World Bank 2001b. p. 61-62.

${ }^{29}$ Wang. 2004.

${ }^{30}$ USDA. 2000.

${ }^{31}$ Economy. 2004.

${ }^{32}$ Wang. 2004. p.8.

${ }^{33}$ World Bank 2002b. P.1.
} 
Toxic pollution loads are undocumented, but estimated to be about $1.7 \%$ of total COD loads representing a significant threat to public health and aquatic systems. High pollution loads in the water will also seriously affect the pollution of coastal zone waters, which today do not meet coastal zone standards for marine aquatic life ${ }^{34}$.

\section{The Trends in Water Demand Are Best Illustrated Sectorally}

Aggregate water use in China (i.e. water for human needs) is traditionally disaggregated into four categories - two reflecting production related demand by farms and factories (agriculture and industry) and two reflecting consumption related demand by households (rural and urban) (Table 3.1).

Table 3.1 China: Water Use

\begin{tabular}{|c|c|c|c|c|c|c|c|c|c|c|c|}
\hline & \multicolumn{8}{|c|}{ Water Use } & \multicolumn{3}{|c|}{ Growth Rate } \\
\hline & \multicolumn{2}{|c|}{1980} & \multicolumn{2}{|c|}{1993} & \multicolumn{2}{|c|}{1997} & \multicolumn{2}{|c|}{2002} & 80-02 & $80-97$ & $97-02$ \\
\hline & $\mathrm{BCM}$ & $\%$ & $\mathrm{BCM}$ & $\%$ & $\mathrm{BCM}$ & $\%$ & $\mathrm{BCM}$ & $\%$ & $\%$ & $\%$ & $\%$ \\
\hline TOTAL & 444 & 100 & 519 & 100 & 557 & 100 & 550 & 100 & 1.0 & 1.3 & -0.2 \\
\hline Production & 416 & 94 & 469 & 90 & 504 & 91 & 488 & 89 & 2.7 & 1.1 & -0.7 \\
\hline Agricultural & 370 & 83 & 380 & 73 & 392 & 70 & 374 & 68 & 0.04 & 0.3 & -1.0 \\
\hline Industrial & 46 & 10 & 89 & 17 & 112 & 20 & 114 & 21 & 4.3 & 5.4 & 0.4 \\
\hline Domestic & 28 & 6 & 50 & 10 & 53 & 9 & 62 & 11 & 3.7 & 3.7 & 3.3 \\
\hline Urban & 6.8 & 1.5 & 24 & 4.6 & 25 & 4.4 & 32 & 5.8 & 7.3 & 7.9 & 5.3 \\
\hline Rural & 21.3 & 4.8 & 26 & 5.0 & 28 & 5 & 30 & 5.4 & 1.5 & 1.6 & 1.4 \\
\hline
\end{tabular}

\subsection{Water Demand for Production purposes - by Farms and Factories}

Agriculture: Agriculture remains the largest user of water in China - accounting for $70 \%$ of the total. However, in the 20 year period from 1980 to 2002, water used annually in agriculture increased only marginally from 370 billion $\mathrm{m}^{3}$ to 374 billion $\mathrm{m}^{3}$ (i.e. by a mere $2 \%$ over two decades) (Table 3.1). In fact, the amount of water used for irrigation actually declined by over $4 \%$, from 358 to 343 billion $\mathrm{m}^{3}$ (between 1980 to1993) as industrial and urban needs pre-empted agricultural needs ${ }^{35}$, and as productivity (efficiency) of water use in agriculture increased.

The role of water pricing in rural areas of China is negligible because, for a long time, government policy kept water prices low as part of a larger strategy to keep farmers in their fields in order to avoid the huge social implications of a rush to the cities. This has had the side effect of encouraging wasteful use of water in inefficient crops and activities $^{36}$. China recently re-emphasized the policy of food (grain) self-sufficiency.

\footnotetext{
${ }^{34}$ Wang. 2004. P.7.

${ }^{35}$ Wang. 2004.

${ }^{36}$ Generally, water is not measured for individual farms or groups of farms. Instead water charges are based on crop type / area planted at the diversion point quite a bit upsteam. This could change with the
} 
Despite that, there has been some progress in shifting to less water-intensive crops and activities in agriculture. However, this shift has been brought about through administrative means rather than through economic pricing of water.

Industry: Industry has been the second most important source of demand for water. Since economic reforms were initiated in the early 1980s, China's economic growth has been rapid, particularly in the non-agricultural sectors. Between 1980 and 2002, water use in industry increased from 46 to 114 billion $\mathrm{m}^{3}$, an increase of $250 \%$ in two decades (Table $3.1)$. Industry now accounts for $21 \%$ of the total ${ }^{37}$. Together the production sectors account for $90 \%$ of water demand.

Some have argued that water demand by industry may be decelerating as industries are becoming more water-efficient or shifting towards sub-sectors with lower-water requirements ${ }^{38}$. The evidence for this, however, is still anecdotal. Even if a shift is occurring, there is still the problem that Chinese industries as recently as the late 1990s were still consuming 4-10 times as much water as their counterparts in more industrialized countries $^{39}$.

\subsection{Water Demand for Consumption Purposes - by Households}

Rural: Rural residential demand for water was 21 billion $\mathrm{m}^{3}$ in 1980, 4.8\% of total use. By 2002, it had increased to 30 billion $\mathrm{m}^{3}$ or $5.4 \%$ of the total.

As recently as 1997, according to the census of agriculture, only $17 \%$ of rural households had access to tap water. A major program to put in tap water systems for rural villages has been underway now for many years. As this program progresses, more households will have access to regular supplies of tap water, and domestic/residential consumption of water in rural areas is expected to increase ${ }^{40}$.

Urban: Urban residential water demand was insignificant in 1980 at $1.5 \%$ of the total. However, in the two decades 1980-2002, China entered a major phase of urbanization. The number of residents in China's cities more than doubled -- from 191 million to an estimated 459 million and their per capita income has increased even more rapidly. As a result the urban residents' share of total water use has quadrupled to almost 6\% (in absolute terms urban water consumption in this period increased from 7 billion $\mathrm{m}^{3}$ to 32 billion $\mathrm{m}^{3}$ ) as urban residents bought washing machines and rented apartments that included flush toilets and individual shower facilities, activities that increase per capita urban water use. Urban areas experienced the biggest increase in water use relative to

establishment of 'water user associations' (WUA) and the introduction of water measurement and water charges based on volumetric consumption.

${ }^{37}$ Water withdrawals for industry on average in high-income countries: $59 \%$ of total water use. Low-income countries: $8 \%$ of total water use.

http://www.wateryear2003.org/en/ev.php-

URL_ID=1607\&URL_DO=DO_TOPIC\&URL_SECTION=201.html

${ }^{38}$ University of British Columbia. Center for Human Settlement,

${ }^{39}$ Wang and Somik, 1997.

${ }^{40}$ USDA. 2000. p.26. 
other sectors in the last two decades ${ }^{41}$ and now account for as much water use as in rural areas.

Per capita water use in cities varies greatly by region. In some areas, such as BeijingTianjin, water use is probably rising at the quickest rate: annual domestic demand in Beijing rose from 552 million $\mathrm{m}^{3} /$ year in 1993 to 829 million $\mathrm{m}^{3}$ in 2000. Despite that in Tianjin -- in the dry Hai basin -- residents still use only 135 liters of water per day, or less than $40 \%$ of the 339 liters per day used by residents in the wet urban areas in the southern province of Guangdong ${ }^{42}$.

\section{Policy and Investment Implications}

China is a large country with a complex economy. Generalizations and "one size fits all" type recommendations are likely to be misleading. Unfortunately, more nuanced solutions to location-specific problems are difficult to summarize and complicated by the fact that some of the necessary information is not easily available in public documents, nor consistent across sources (in part because information sources vary in terms of their definitions and coverage and are rarely complete ${ }^{43}$ ).

Many of the problems cited in the previous sections are well known to Chinese authorities and they have initiated a wide range of programs to cope with them. The status of implementing these programs is summarized in the Ministry of Water Resources' (MWR) Water Resources Report ${ }^{44}$. In addition to the comprehensive overview ${ }^{45}$ of China's water needs completed by MWR in 2002, the World Bank prepared a strategy document ${ }^{46}$ in 2003, which outlines comprehensively the key actions necessary for the future. In neither of these documents is there a quantitative assessment of how much of the different problems will be resolved by the different actions. Nor were the actions fully costed and sequenced. But they do provide an excellent array of actions to be implemented.

\footnotetext{
${ }^{41}$ Overall, domestic household consumption per capita has risen tenfold in the last five decades to 240 liter a day per person in 2000. University of British Columbia.

42 USDA. 2000. p.26.

${ }^{43}$ Many instances of water scarcity are highly localized and are not reflected in national statistics. In addition, the accuracy and reliability of information vary greatly among sub-national regions, and categories of information, as does the year in which the information was gathered. As a result, establishing consistency between different variables within and across time periods is difficult. All data should be considered order of magnitude estimates.

${ }^{44}$ MWR. 2003. “China Country Report on Sustainable Development - Water Resources.”

$45<$ Chinese Title> “Zhong Guo Ke Chi Xu Fa Zhan Shui Zi Yuan Zhan Lue Yan Jie Bao Gao Ji” (Di Wu

Juan \& Di Jiu Juan December 2002) < English Title> Strategies for Sustainable Water Resources

Development in China. (Water Publication December 2002) http://www.waterpub.com.cn/index.htm

${ }^{46}$ World Bank. 2003a.
} 
By contrast, a joint Bank China study ${ }^{47}$ for the $3 \mathrm{H}$ basins ${ }^{48}$-- the areas of most acute water shortages -- did quantify the issues and options. It projected municipal and industrial water needs in the future, treating water requirements for irrigation as residual. On this basis it projected shortages of $56.5 \mathrm{bcm} /$ year in 2050 for the area under investigation. Increasing water prices and improving efficiency could reduce projected shortages by $22 \% 49$. Reusing treated water could reduce shortages by another 4\%. However, even with demand management and reuse measures shortages on the order of $42 \mathrm{bcm}$ (resulting in economic losses of Y59 billion/year) would remain. Implementing the South-North transfer could reduce the remaining shortages by $19.44 \mathrm{bcm} /$ year, but will not close the gap. For this reason it does not make sense to project water demand for irrigation as if supplies can be augmented at reasonable cost. Instead it is better to project (i) future water resource availability and (ii) demand by Municipalities and Industries (M\&I). The difference between the two will define the residual available for irrigation -- which in turn will define priorities for high value, low water use crops. Table 4.1 below shows the declining water availability for irrigation for different GDP growth rates through 2020 in the 3H basins.

Table 4.1. 3-H Basin Water Availability and Use Projects with Different Annual Growth Rates

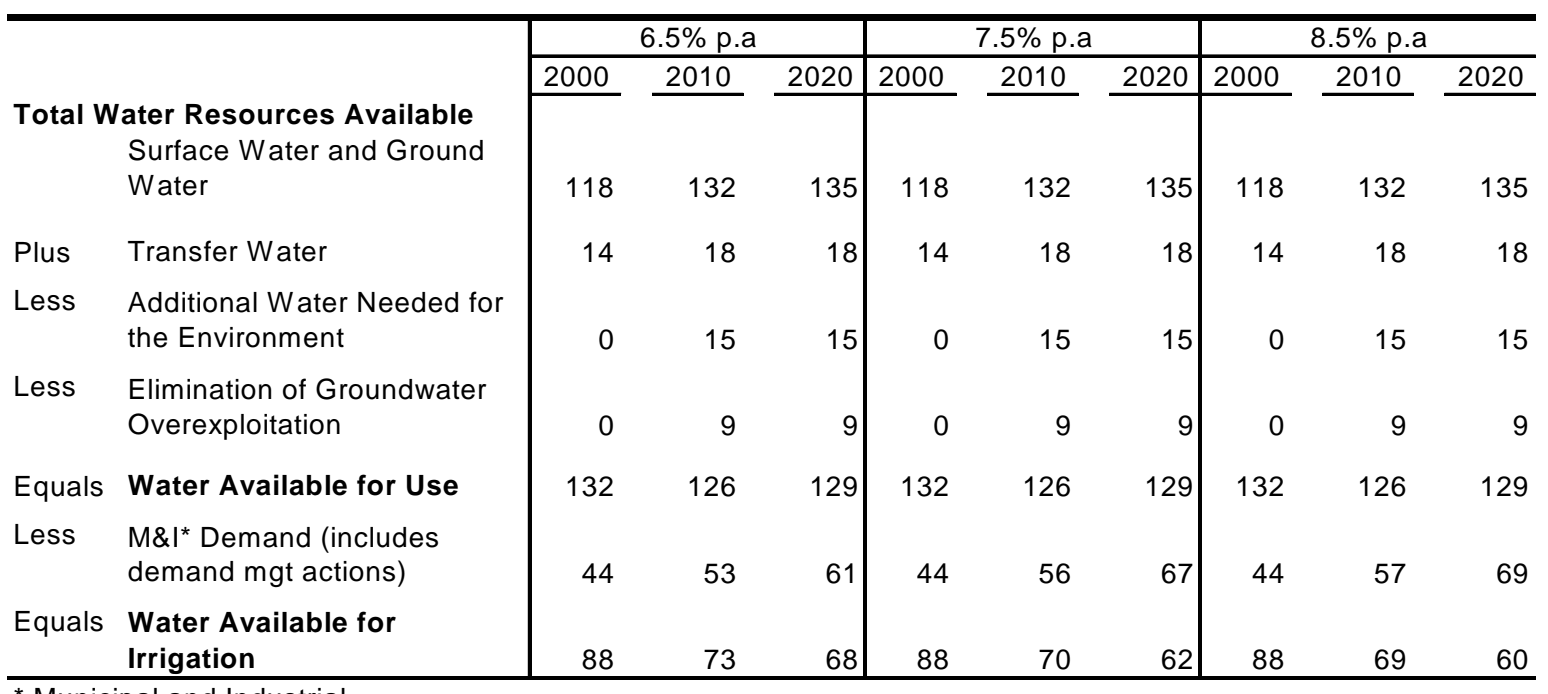

* Municipal and Industrial

Source: World Bank 2001

It is clear from reviewing these and other documents and reports on many of the projects that have been implemented recently, that China has had more success in dealing with investment needs to control flooding, restore forested watersheds, and to improve water

\footnotetext{
${ }^{47}$ World Bank. 2002b. v1 p.viii.

${ }^{48}$ 3H basins: Hai River, Huai River and Huang (Yellow) River. The 3-H basins are the bread baskets of China, producing 67 percent of China's wheat, 44 percent of its corn and 72 percent of its millet. The 3-H basins also account for 65 percent of China's peanuts, 64 percent of its sunflower, 50 percent of its sesame and 42 percent of its cotton. Forty percent of China's cultivated area is in the 3-H basins. They produce 31 percent of China's gross industrial output value, while the 3-H basins have only about 10 percent of China's water resources. Two out of every five people in China live in the 3-H basins which contain 424 million people.

${ }^{49}$ World Bank. 2002b. v1 p.viii.
} 
supply and waste water treatment than in managing demand through better pricing and conservation policies, and better institutional coordination of integrated water management programs at different jurisdictional levels - though there have been some successes (as in the Tarim Basin Project ${ }^{50}$ ) that have not yet been generalized. The essential point emerging from this review is that expanding water supply -- at increasing marginal costs ${ }^{51}$-- in a context where it is not being used efficiently, will only increase the drain on public resources and be ultimately unsustainable.

\section{Implementing effective demand management policies requires dealing with public goods differently from dealing with private goods}

Public Goods: By definition, public goods cannot be provided by markets. In the absence of feedback through market prices/ signals, managing the environmental component of public goods requires feedback from scientific knowledge, (and public commitment to act on that knowledge) to restore critical ecosystem functions affected by inadequate and degraded (/polluted) water availability. Similarly, managing the social component of public goods requires feedback from communities, (and public commitment to act on this feed back) to correct damaging consequences to public health, as well as, to the livelihoods of vulnerable households arising from inadequate and degraded water availability.

Private Goods: Expanding the role of markets and market price signals as a feedback mechanism in water allocation will go a long way in helping conserve the resource and allocate it to the highest economic use, as well as, to send signals on priority investment requirements. Expanding the role of water markets and prices is a corollary of expanding the role of markets in the production of private goods and services. However, the expansion of water markets and prices presupposes progress on establishing the institutional framework on property rights (water rights/entitlements), valuation, and appropriate measurement. Taxes and subsidies, as well as, educating farmers, firm managers, and households in water conservation options can also augment the role of water pricing where the latter provides insufficient information and incentives on the allocation of water.

\subsection{Trends Affecting Future Demand Projections}

\subsubsection{Elasticity of Water Demand with Respect to GDP}

As noted above agriculture is still the largest consumer of water in China, but growth in demand has been greatest in urban and industrial use. In 2002, China consumed about 550 billon $\mathrm{m}^{3}$ of water annually, of which $68.8 \%$ was used for agriculture, $21 \%$ for industry and $11 \%$ for household purposes (Table 3.1). Demand for water grew at an annual rate of

\footnotetext{
${ }^{50}$ China - Second Tarim Basin Project, World Bank Project Appraisal Document 1998

${ }^{51}$ The likely capital cost of water resulting from the S-N transfer could be on the order of 245 billion Yuan for a flow of $19 \mathrm{bcm} /$ year. Depreciating these costs and adding operating costs will likely require prices well in excess of those currently prevailing of less than a Yuan/cu m. (World Bank. 2001 "China Agenda for Water Sector Strategy for North China.” v 1 Main Report. P.55, 85 and 98 Table 4.20.)
} 
7.3\% for urban households and 4.3\% for factories between 1980 and 2002 even as water demand for rural households and farms remained almost unchanged (Table 3.1).

Using GDP in constant 1990 prices $^{52}$, the elasticity of water demand in industry with respect to GDP (at .45) is still much higher than the elasticity of water demand in agriculture (at .01) in the period 1980-2002 (see table 4.2). However, this period really consists of two sub-periods with very different trends. In the period 1980-1997 the elasticity of water demand in industry was 10 times higher than it was in the period 19972002. In the case of agriculture the elasticity was actually negative in the second period.

Table 4.2. China: Elasticity of Water Use with respect to

\begin{tabular}{l|rrr}
\hline & $1980-97$ & $1997-2002$ & $1980-02$ \\
\cline { 2 - 4 } TOTAL & $\mathbf{0 . 1 3 3}$ & $\mathbf{- 0 . 0 3 2}$ & $\mathbf{0 . 1 0 3}$ \\
Agricultural & 0.034 & -0.124 & 0.005 \\
Industrial & 0.539 & 0.049 & 0.447 \\
& & & \\
Urban & 0.785 & 0.691 & 0.767 \\
Rural & 0.156 & 0.187 & 0.162 \\
\hline
\end{tabular}

This suggests that the production sectors were able to grow even as they reduced their demand for water. However, in the case of agriculture, real output grew at only half the rate it did in the previous period ( $2.8 \%$ vs. $5.5 \%)$ suggesting water shortages may be affecting growth opportunities, which is consistent with anecdotal evidence. Real industrial growth rates also decelerated from 12\% to 9\% between the 1980-1997 and 1997-2002 periods. Again there have been anecdotal observations that water shortages are affecting growth opportunities in the sector. Thus, the observed drop in water use elasticity with respect to GDP growth has been accompanied by a drop in agricultural and industrial growth rates as water shortages limited investment and therefore growth opportunities. While there is substantial scope for improving water use efficiency in agriculture and industry in China, it is not clear whether over a 40-50 year period, improved efficiencies will be sufficient to fully offset water use requirements associated with very high GDP growth rates, as was done in the five year period 1997-2002.

\subsubsection{Long-term Water Use Trends}

In the absence of a China-wide simulation model it is difficult to analyze the implications of different scenarios. However, some aspects of future water demand can be analyzed with the aid of a simple simulation model. This is primarily an illustrative exercise to understand the key drivers of water demand at a broad-brush level. It is not capable of identifying location-specific policy priorities, or planning targets.

The key variables in the model are population forecasts, changes in the urban-rural composition of the population, changes in the per capita water demand of rural and urban households, changes in the composition of production between primary (agriculture plus),

\footnotetext{
${ }^{52}$ World Bank 2003b.
} 
secondary (manufacturing plus), and tertiary (services) activities. With these few variables one can show the sensitivity of the "aggregate demand for water" to different average GDP growth rates to 2050 -- if water demand per yuan of output does not change significantly in the various sub-sectors. This then provides a backdrop for comparing actions to aggressively increase the efficiency of water use in the sub-sectors vs. actions to aggressively increase water supplies - recognizing that the composition of the action portfolio will vary by region, river basin, and even locality.

The projections use

- Two scenarios for population in 2050: (1) the UN medium term projection, assuming a growth rate of $0.2 \%$ per annum with the population peaking and then leveling off at 1.4 billion people by 2050; (2) the population of 1.6 billion in 2050 which was used in the $3 \mathrm{H}$ study (and implicitly assumes a $0.45 \%$ per annum growth rate).

- The same urban-rural split and GDP structure for 2050 used in the 3H study.

- The assumption that the demand for water of rural and urban households will continue to grow but at different rates - varying between a fast one akin to the explosive growth in the 1980-1997 period, and a slow one akin to the growth in the period 1997-2002.

Using these very simple assumptions, we find that the doubling of overall population growth rate from $0.2 \%$ to $0.45 \%$ p.a. has a negligible impact on water demand. The increase in the urban share of the population, however, is more significant particularly if the average demand for water of urban households continues to grow rapidly. But these changes in demand - not excessive in their own right -- will be more difficult to accommodate if there is not also a substantial deceleration and possibly even a decline in water demand by agriculture and industry.

In other words, if the unit water consumption patterns of the latter do not change significantly, even though their share in GDP decreases, shortages will continue to grow and average GDP growth rates $>5 \%$ p.a. over 50 years (say 7\% p.a. in the first till 2025 and $4 \%$ thereafter) will be difficult to sustain, as they could generate water demand in excess of China's ability to supply at a reasonable cost.

Even a 4\% p.a. growth rate for the country through 2050 could generate the need to increase water supply in many growth areas in excess of $100 \%$. To put this required increase in water in perspective - it is worthwhile to note that in the explosive GDP growth period of the last 20 years, (with its attendant industrialization and urbanization transformations) aggregate water demand grew by only 25\% from 440 BCM to 550 BCM - with the $3 \mathrm{H}$ river basins and key metropolitan regions experiencing so much water shortage that they have had to resort to diverting water from downstream rural users and estuaries, as well as, pumping aquifers at a rate faster than replenishment -- which is ultimately unsustainable. 


\subsubsection{In the Scenarios above the Real Pressure on Water Demand Emanates from Lack of Efficiency Improvements in Water Use in Agriculture and Industry}

Thus, there is a strong premium on lowering water consumption patterns in the production sectors, i.e. towards agricultural and rural activities that are less water-intensive per unit of output, and to increase the re-use of water in industry.

Clearly increasing the role of water pricing is necessary but not sufficient to ensure more efficient use of water. Government has recognized this and has started the process. But it will have to stay the course and steadily increase prices. At present, water prices are set administratively, without adequate and timely feedback, as would happen with market prices that reflected the balance between the costs of increasing supply versus benefits foregone if supply is not increased.

\subsection{The Utility of Prices as a Signaling Device Can Be Increased If Markets to Trade Water Rights Can Be Implemented with Appropriate Safeguards /Complementary Actions to Address Public Goods}

The average price of water increased from almost nothing, prior to 1980, to 0.038 USD per $\mathrm{m}^{3}$ in 1988, to 0.15 USD per $\mathrm{m}^{3}$ in $2003^{53}$. Recent decisions ${ }^{54}$ suggest prices in some urban areas will be increased further in the next two years (e.g. in Beijing to 1.29 USD per m ${ }^{35}$ nearly double the current price there). But the overall average price is still low both in terms of what is needed to reduce water wasted by households and industries (as noted earlier Chinese factories use 4-10 times as much water as factories in developed countries to produce an equal amount of goods), and by comparison with other countries where markets determine a larger proportion of prices -0.47 USD per $\mathrm{m}^{3}$ in South Africa, 0.51 USD per $\mathrm{m}^{3}$ in the USA, and 1.45 USD per $\mathrm{m}^{3}$ in Germany ${ }^{56}$.

There have been many studies exploring water-pricing reforms in China including different pricing methods (volumetric/marginal cost pricing; tiered pricing; two part tariffs < life-line plus commercial>; input-output pricing; per area pricing; etc.) ${ }^{57}$. Most have been theoretical. The $3 \mathrm{H}$ basin study included some estimates of price elasticity. But there have been no empirical studies of the impact on production (epecially in irrigation) of increasing prices or moves to increase cost recovery. Nor have there been any studies of willingness to pay. One study for irrigation 58 was underway in 2004.

\footnotetext{
53 IWHR. 2003. “China’s Reform of Water Prices for Irrigation: Effectiveness and Impact.”

${ }^{54}$ Wall Street Journal, June 15, 2004.

55 The article uses 0.54 USD per ton (re-calculated by 1 ton to $0.417 \mathrm{~m}^{3}$ )

56 The UN World Water Development Report 'Valuing Water'

57 (Wang, etc., 2003; Li, etc. 2003 ; Jiang, 2000 ; Jia, 2000) Dinar, Ariel. 2004. “ Pricing Irrigation Water” Resources for the Future.

58 op cit. China’s Reform of Water Prices for Irrigation: Effectiveness and Impact.
} 
More specific recommendations are included in boxes 4.1 and 4.2 below:

\section{Box 4.1. Addressing the Water Scarcity Issue in Agriculture through Participation and Water Rights}

"A major water conservation program in irrigated agriculture is needed that focuses on increasing the agricultural production yield and economic value of production per unit of water consumed, while at the same time drastically reducing consumption. China has already made some progress in this regard, but a major escalation in effort is required. There is a need for a major program of agricultural research and training of technicians and farmers to increase yields and production value in conditions of partial supply and rain fed agriculture, as well as for full irrigation supplied areas. China's existing water savings program that focuses mainly on increasing irrigation system efficiencies is inadequate and partially misguided. Much of the water losses in existing irrigation systems returns to the surface or groundwater system, and reducing these losses also reduces these return flows.

Often improving irrigation system efficiencies results in an increase in agricultural consumption of water and a decrease in return flows, and therefore results in more water consumption rather than less. The Bank supported Water Conservation Project, which began implementation in 2001 and the GEF Hai Basin Integrated Water and Environment Management Project focus on integrated irrigation, agriculture and on-farm management measures with the objective of increasing yields and value per unit of water consumed or in other words per unit of evapotranspiration (ET). These projects will develop and demonstrate ways to achieve this objective.

Measurement of water extracted from wells in irrigated areas is also usually not metered or charged for. One of the major principles to implementing an effective system of water conservation through demand management therefore will be implementing a system of measurement and volumetric charging at the lower ends of the irrigation delivery systems and in well systems. Water user associations (WUAs) can takeover responsibility for the operation and maintenance of lateral-level irrigation systems with good measuring devices installed and monitored at the point of delivery to these systems.” 


\section{Box 4.1 (continued)}

"A third critical area of emphasis is the design and implementation of mechanisms that will facilitate the functioning of a system of tradable water rights. Such a system would make a major contribution to increasing the value of production per unit of water consumed in irrigated agriculture areas and to the reallocation of water from agriculture to priority uses. A significant amount of informal water trading already goes on in China. Chinese water law includes provisions for the issuing of water licenses, but the issuing and enforcing of water licenses in irrigation areas is not widespread. At each point of water measurement, a corresponding water right should be issued that includes: (a) a flow rate; (b) a total volume of allowable annual delivery/extraction; and (c) a total volume of allowable annual consumptive use. The sum of all of the consumptive use rights for a river basin or aquifer should not exceed the allowable total consumptive use in the basin or aquifer in order to have sustainable water resources use and management. Once the consumptive use water rights issued equal the allowable total consumptive use rights in a basin, no further water rights should be issued. No water diversion or well drilling/pumping should be permitted without a corresponding water right. Once a complete system of water rights/measurement is operational, then a system of tradable water rights could begin to function. To ensure maintaining a water balance and no negative impacts on third parties, the consumptive use right is the right that should be traded. All water rights trades should be registered and approved by the government authorities ensuring no impact on third parties. Without a complete system of consumptive use water rights and measurement, tradable water rights will not be able to aid in the reallocation of water within a sustainable water resources management system and therefore, trading in water rights should be restricted."

Source: World Bank. 2004. p. 3-4

\section{Box 4.2. Addressing Water Scarcity in Agriculture through Complementary Institutional Reforms Such as Measurement and Monitoring}

"The action plan recognizes the important social and political (including food security) implications of maintaining adequate water supplies to rural areas for agriculture. At the same time, the cost to the government of supplying large volumes of water to low valueadded agricultural activity is no longer sustainable. Thus, the action plan focuses on structural and nonstructural components.

The action plan recognizes the need to increase participatory mechanisms and to continue management reforms in order to develop innovative models for irrigation district management, including joint stockholder cooperatives, water supply companies, water user associations and self-financed irrigation and drainage districts. The proposed improvement components run in parallel with existing Chinese government programs, particularly the comprehensive agricultural development (CAD) program, the large irrigation district (LIS) program, and the water-saving program. These are focused on demand management, increased efficiency of water use, and appropriate pricing reviews without any augmentation of supply. The exception might be water supply derived from wastewater reuse schemes that may be available for market gardens in the peri-urban areas around cities. The action plan however calls for increased commitments to these objectives." 


\section{Box 4.2. (continued)}

"A key aspect that needs to be strengthened in conjunction with the participatory institutional and water price measures is water measurement and volumetric water charging. Although everywhere in China irrigation water charges are stated in terms of cubic meters of water use, in reality there is a major lack of adequate water measurement at the lower end of the irrigation systems and the actual calculation of the water charge is based on the irrigated area and an average water usage rate, rather than on a measured delivery amount. Although there are no accurate data that can be generalized, anecdotal data have shown in China that when transparent water measurement and volumetric charging are introduced in specific areas (i.e. where there are no major distortions due to water shortages) in conjunction with water user associations, there is a reduction in the amount of water used. The action plan includes a program to introduce and strengthen water measurement and volumetric charging in conjunction with water user associations.

The third part of the action plan for agriculture recommends that an integrated comprehensive approach be adopted in order to effect real water saving from the standpoint of the hydrological system. The integrated approach does not rely solely on engineering measures unlike the present National Irrigated Agricultural Water Saving Program, but instead focuses on (a) physical improvements to canal and on farm irrigation and drainage systems, (b) agronomic measures and (c) irrigation management measures.”

Source: Gunaratnum. 2004. p. 22

\subsubsection{Addressing the Social Implications of Increasing the Role of Water Pricing}

Moving towards economic pricing of water requires that one addresses the impact on vulnerable groups in a manner that does not undermine improvements in allocative efficiency.

For example, encouraging agriculture to shift out of water intensive activities (e.g. from wheat to livestock) through a steady increase in water charges could adversely affect many poor and vulnerable rural households. Essentially, as in the analysis on WTO Accession ${ }^{59}$ removing implicit subsidies on a key input into agriculture (i.e. water), is likely to displace farmers and individuals with limited alternatives.

"Beijing farmers are generally far poorer than their urban cousins, rural water costs only 0.2 renminbi (Yuan) a cubic meter....but competition for resources is nevertheless growing as Beijing's urban suburbs expand, making the use of precious water in the fields increasingly irrational" 60 . "Farmers cannot compete economically with industry for water in China (or anywhere else). The arithmetic is stark. A thousand tons of water produces one ton of wheat, which has a market value of 1,600 Yuan (\$200), while a thousand tons of water used in industry yields an estimated 112,000 Yuan $(\$ 14,000)$ of output, or 70 times

\footnotetext{
${ }^{59}$ Anderson, Kym. 2002.

${ }^{60}$ Holland, Lorien. 2000.
} 
as much"61. In other words, a rise in prices to reflect economic scarcity is more easily absorbed by industrial enterprises (and urban households) than by many farmers (and rural households) engaged in grain production ${ }^{62}$.

The competition for water could substantially reduce the acreage devoted to waterintensive, low value grain production ${ }^{63}$. Reducing grain production by 13 million tons would free up $13 \mathrm{bcm}$ of water (at current water use productivity rates in grain production of $1 \mathrm{~kg} / \mathrm{cu} \mathrm{m}$ ) which is equivalent to the current excess water use in the Hai basin. However, reducing grain production is at odds with the current policy of food (grain) selfsufficiency. The reduction in grain output will be less if water system efficiency improvements or implemented. For example, reducing evaporation and transpiration could double water use productivity and cut the amount by which grain production would have to be reduced. But even then, it could be difficult to fully reconcile the competing objectives of no reduction in grain production while eliminating water deficits.

Returns to water use can be increased by shifting to higher value crops but this could displace some grain farmers lacking the skills or complementary resources (credit and technical assistance) to manage the cultivation of higher value commercial crops. Some of these displaced farmers and households can be absorbed in other non-farm rural activities. But many cannot. This will create a push factor, stimulating rural to urban migration. This will not be undesirable, if a couple of precautions are addressed and implemented:

Programs are introduced to facilitate rural to urban migration of vulnerable populations that cannot shift to other rural activities. These programs will have to also concentrate on providing assets to the rural poor (including education, training, improved property rights to access credit) so they have the skills to compete in urban labor markets (or become entrepreneurs in legal SMEs) and avoid falling below the poverty line again.

New urban centers are identified that can absorb the migrant population both to satisfy the need to increase overall economic productivity (agglomeration economies, etc.), but also the need to avoid the increasingly costly water scarcities in existing large metropolitan centers. With some important exceptions, encouraging urbanization (and new infrastructure development) in areas that are not water scarce, or likely to become water scarce, may be an efficient long-term strategy. As is evident from table 1.1 above there has been a dramatic demographic shift from rural to urban areas between 1980 and 2000 (with the urban share increasing from $19 \%$ to $36 \%$ and the rural shares declining from $81 \%$ to $64 \%$ ) which is associated with a quadrupling of the urban share in total water demand. However, there has been no noticeable demographic shift from North to South (relative shares remaining almost constant at $42 \%$ and $58 \%$ respectively)

\footnotetext{
${ }^{61}$ WWI. 2004.

${ }^{62}$ Dinar, Ariel. 2004.

63 China’s water shortages could result in massive grain imports and higher global grain prices. (Lorien Holland 2000.)
} 
despite the growing water scarcities in the North ${ }^{64}$. This is an anomaly that requires further analysis -- but lack of adequate price signals on the real economic costs of water could be one factor.

Efforts are made to reduce the exposure to a set of risks that can arise if the poor rural migrant populations are forced to live on cheaper land (e.g. in vulnerable flood plains, or near polluted water basins).

Thus, to address water scarcities it is not going to be sufficient to focus just on economic efficiency criteria. Social issues also need to be addressed as an integral part of a broader program

\subsubsection{Addressing the Environmental Implications of Increasing the Role of Water Pricing}

Demand management strategies - including conservation measures -- are essential not just to reduce water wastage, but also to reduce the need for costly inter-basin water transfers. Allowing or encouraging continued urbanization also requires that the collateral damage associated with expanding urban water demand be lowered. Using freshwater would be less consequential if water abstracted upstream could be returned to river flows in good condition to be used again downstream. This can only be done if water polluted through urban and industrial use is treated appropriately first. Thus, in urban areas -- in comparison to rural areas -- not only must water prices go up faster, but so should the charges for waste water discharges and other pollutants (combined with better monitoring and information disclosure, and enforcement of appropriate standards).

\subsection{Reducing the Cost of Wastewater Treatment and Improving Its Monitoring}

Increasing wastewater charges (specially the speed by which charges increase) will be easier if there is better monitoring and information disclosure, and if more wastewater is treated for re-use. The latter requires that increases in wastewater charges be complemented by lowering the cost of investment in wastewater treatment plants.

"Public Disclosure of Information" on water quality and "Community Consultation" can improve feedback and facilitate better monitoring: Jiangsu Province, SEPA, and the World Bank have done research on pilot versions of community consultation and feedback processes, as well as Public Disclosure of Information and determined that they have the potential to be scaled-up ${ }^{65}$.

\footnotetext{
${ }^{64}$ The only caveat is the possibility that official data underestimates the extent of migration of the population from the north to the South analogous to the underestimation of the population in urban areas due to unregistered (non-hukou) migrants as noted in Fan, Cindy and Vernon Henderson.

${ }^{65}$ Jiangsu Environmental Protection Bureau Conference on "Environmental Information Disclosure” August 13, 2004.
} 
There is a need to improve Local Budgetary relationships: Many waste water treatment plants have been built but are operating well below capacity, or even zero capacity, because revenues collected from customers are transferred to the general city budget and not allocated to ensure that the treatment plants have the necessary resources with which to operate 66 .

There is a need to improve Investment Coordination across metropolitan regions: It is clear that there are economies of scale and optimal size of wastewater treatment plants. When municipalities respond to national directives by trying to implement their own separate wastewater treatment plants there is a real possibility that the overall national costs of the wastewater treatment program will be excessive.

Widening options considered for wastewater investment decisions may make a difference: As noted in the World Development Report 200367, New York City found that it was cheaper to repurchase land along part of its watershed that had been sold for development, than to build an expensive water treatment plant. This was possible because the topography provided for a natural filtration process that was very effective. This will not be an appropriate option in all cases, but it may be in some cases. More importantly, it may show the possibility of other more cost-effective solutions, which combine land development restrictions, and restoration of local watershed filtration capacities to reduce the amount of water needing treatment and therefore the cost of the overall program for wastewater treatment in China.

Additional specific actions are included in box 4.3:

\section{Box 4.3. Reducing Water Pollution}

"The action plan recommends structural, nonstructural and institutional investments and programs to strengthen existing government efforts designed to improve declining water quality trends.

Pollution from urban municipal sources would be managed by the use of updated municipal sewerage systems, including collecting sewers and treatment plants, designed to have capacity also for receiving industrial wastewater. This use would result in large savings both to the municipality and industries because of economy of scale for treatment for removal of degradable organics (with the provision that participating industries would first remove toxic and other objectionable substances by using in-plant treatment before discharging to the municipal system). The treated municipal effluent would be reused to the extent practicable as water supply for irrigation and for industries. In addition, the municipal systems would include provisions for effective use of onsite excreta disposal units for homes and buildings not connected to municipal sewers. The same provision would apply to rural homes.”

\footnotetext{
${ }^{66}$ Based on informal communications with the author of on-going "City Development Strategy" (CDS) in 11 cities in China.

${ }^{67}$ WDR 2003a. p.26.
} 


\section{Box 4.3. (Continued)}

"Industries in urban areas would reduce waste production by use of cleaner technology and would dispose of wastewater, after removal of toxics, by reuse, discharge to environment, or discharge to municipal systems. Rural industries, including livestock operations and township and village enterprises (TVEs), represent a large pollution source that has been given little attention. Addressing the problem, the action plan would require livestock operators to utilize stabilization treatment ponds, and would require TVEs to utilize adequate treatment facilities for TVE types that can afford this, and otherwise plan for gradual phasing out of TVE types that cannot afford to comply. The overall pollution control program would also include attention to promoting adequate solid waste management in both urban and rural sectors, so that these wastes would not be left unmanaged and subject to being flushed into waterways by surface runoff.

The nonstructural part of the action plan for water pollution is equally ambitious. The main components include (a) review of water quality standards, both ambient and emission, and revision of these to be practicable and appropriate for use in China, including the $3-\mathrm{H}$ basins, with emission standards based on mass rather than concentration units; (b) establishment of a permit system whereby municipalities can control waste discharges from industries, including effective monitoring and enforcement of their performance; (c) use of the environmental impact assessment process for all major waste polluters to reinforce the permit system operations; and (d) coordination of the basin water-quality monitoring programs operated by the State Environmental Protection Administration (SEPA) and MWR to eliminate overlapping and to fill important gaps."

Source: Gunaratnum. 2004. p. 23

\subsection{Augmenting Water Supply}

Demand management policies through market prices may not be sufficient to deal with the full range of environmental water problems facing China. It is easier, to introduce water charges when scarcity has emerged but critical thresholds have not yet been crossed. It is more difficult to introduce water pricing and waste water charges when implicit rights have been acquired and critical thresholds crossed.

Two such thresholds in China are: (1) the lack of adequate water in rivers to ensure year round flows to flush the rivers, transport silt to the delta, and avoid ecosystem damage down stream - all of which are already occurring; and (2) the need to restore some, if not all the ground water, that has been over-pumped in the recent past. In both these cases, more water flow has to be restored to the ecosystem and aquifers.

It might be possible to do that by setting the price so high that existing users voluntarily renounce some of their water claims. But in the absence of water markets and well-defined water rights it may not be possible to fully restore the minimum requisite water abstracted from rivers that now run dry. More importantly, ecosystem needs are public goods and by definition difficult to include in water markets (today, when dry weather flows in rivers are 
low, water for environmental needs have to come from a reduction in irrigation). This will require institutional reforms as noted in box 4.4.

\section{Box 4.4 Institutional Reforms to Restore Groundwater}

"The key actions required by the action plan are: (a) definition of groundwater management units with determination of sustainable yields; (b) preparation of groundwater management plans; (c) allocation licensing linked to sustainable yield and undertaken by one department only; (d) licensing of well construction drillers; (e) development of a national groundwater database; and (f) preparation and implementation of a groundwater pollution control strategy, including provision in selected cities for recharging of groundwater by spreading of treated wastewater effluents or of floodwaters on permeable spreading areas, and for injection of treated effluents to establish groundwater mounds to prevent salinity intrusion into freshwater aquifers.”

Source: Gunaratnum. 2004. p.24.

Other investments in infrastructure such as a "catchments reservoirs" and watershed management in "catchments basins", e.g. through re-forestation, to stabilize damaging unevenness in water flows over time are other examples of supply oriented interventions that need to complement demand management policies where there are externalities and public goods involved. For the future, some augmenting of existing supplies e.g. through inter-basin transfers and reuse of waste water will be required. See box 4.5 .

\section{Box 4.5. Water Scarcity and Water Resource Development}

"The proposed action plan recommends two key measures for demand management to reduce water demands to minimum feasible levels: (a) water price increases for all use sectors so that revenues would reflect cost of supply and scarcity, and (b) a series of measures for increasing water use efficiency in all sectors.

These demand management measures alone, however, would not reduce demands sufficiently to match available basin supply. Hence the action plan proposes two key measures for augmenting supply, namely:

(a) systematic increase in reuse of treated wastewaters. As shown by experience in industrial countries, treated municipal wastewaters represent a very valuable source of supplemental water supply for industrial raw water supply and for irrigation of urban area green zones and farming. Hence the action plan would incorporate provisions for planning of municipal sewerage systems to facilitate reuse. Such planned reuse would be subject to regulatory control by use of the permit system, to ensure attention to needs for protecting public health,

(b) interbasin S-N transfer. Because such a transfer is very expensive, a primary goal of the action plan is to reduce the need for transfer to the minimum feasible levels by implementing demand management and institutional reforms, simultaneously with supply augmentation methods. With the supply augmentation measures it is also necessary to improve, rehabilitate and expand all city supply, wastewater treatment and drainage systems on the $\mathrm{S}-\mathrm{N}$ transfer routes to ensure more efficient water distribution and drainage.”

Source: Gunaratnum. 2004. p.21. 


\subsection{There Is a Clear Coordination Function That Requires Addressing Institutional Issues If Policies and Programs Are to Be Implemented Within a Reasonable Budget and Time Frame}

A number of recent World Bank reports such as the "Water Resources Assistance Strategy for China 2002," and the “Agenda for Water Sector Strategy for North China68” provide a useful set of actions that need to be implemented. However, a serious problem noted in both is that: "Current institutional arrangements do not permit a coherent integrated approach to solving these urgent and complex problems due to the fragmented nature of the mandates of the Ministries and uncertain relations between provincial and central governments. Existing river basin commissions operate under the aegis of the Ministry of Water Resources and because they do not include the active participation of the provinces or other ministries, are unable to exercise much influence in regard to water resources management. Water allocations are based on periodic negotiations, which are mostly not honored because of inadequate monitoring, modeling and forecasting, and a lack of institutional mechanisms for enforcement"69. The need to strengthen substantially the role of River Basin Commissions has been noted as a priority institutional change in a number of studies. Also irrigation supply agencies and customer groups need to be reformed. (see Box 4.6)

\section{Box4. 6. Institutional Management of River Basins}

"The role that institutions play in the management of water resources is critical and paramount for the success of the proposed action plan. A number of key recommendations must be implemented to support proper functioning of the action plan's structural components. These include: (a) establishing high-level River Basin Coordinating Councils (RBCNs) in each of the basins, controlled by boards with balanced presentation from both central government and provincial and local governmental agencies; (b) giving the RBCNs authority for determining water resource allocations and developing water resource policies for optimal overall basin water resource utilization; (c) reorienting the existing River Basin Commissions (RBCMs) to serve as the working arms for the RBCNs, including review of water charges for all sectors; (d) establishing provincial water resource coordinating committees for the management of water resources at the local levels; (e) ensuring that only one agency be charged with permits for resource extraction; (f) transferring management of irrigation districts to local institutions following a consultative process; and (g) arranging for enlargement of the scope of the permit system in municipalities that receive expensive imported water to cover all "water handlers," including water supply, water uses, and wastewater treatment and reuse, to ensure optimal use of both local and imported water."

Source: Gunaratnum. 2004. p.24.

\footnotetext{
${ }^{68} 2002$.

${ }^{69}$ World Bank. 2002b.
} 


\subsection{A Broader and More Detailed Analysis of Socio-economic Options Is Needed to Complement the Comprehensive 2002 Study on Technical Water Options for China}

How should China deal with the increasing demand for water arising from its ongoing rapid urbanization and industrialization? Should it emphasize demand management policies -- because water supply is physically constrained (i.e. cannot be augmented locally with current technologies at reasonable economic cost), or should it emphasize investment in infrastructure to ensure greater supply of water in the near and medium term -- because there are no real physical or technical constraints (only economic/financial ones)? Or, if both are needed, what should be the balance in a portfolio of actions ?

The analysis in this note -- regarding current status, trends and projections - suggests the need for more in-depth work for different classes of locations in a framework that is regionally and nationally consistent to quantify the likely cost and impact of action priorities for surface and ground water, based on the actions already outlined in documents cited earlier. With that type of work it should be possible, to indicate the proportion of the problem that is likely to be solved by the different actions, and the likely costs associated with individual actions or groups of actions.

This analysis will have to be augmented with additional work analyzing different scenarios and trajectories of demand. In particular, there is a real need to study willingness to pay and other methods for analyzing demand responses to different pricing options. In the absence of such work it is difficult to give strong prescriptions, many of which are likely to vary by locality in importance.

\section{Conclusions}

Of the many actions discussed in this review, the following three stand out as perhaps the most significant:

(1) Allocate water for public uses (such as estimated ecosystem water needs ) first before allocating water to private uses (industry, residential -- rural and urban, and agriculture as the residual claimant) and regulate both (e.g. to protect public health).

(2) Shift from administrative to price allocation of water -- initially through better technocratic analysis, and eventually complemented through water markets based on fair and transparent allocation of property rights in water. Markets cannot totally replace administrative (quota) allocations for reasons that are well known and implicit in the recommendation above regarding public/private use of water. The balance between the two allocation mechanisms (administrative vs market) will be determined politically, though good technocratic analysis can inform the political debate. 
(3) Improve the institutions involved in water management -- including better coordination of water use through invigorated river basin/watershed mgt commissions and greater involvement of communities in joint monitoring and enforcement through public disclosure schemes.

Two important ancillary recommendations are:

(i) Increase urban water recycling through more reliable and cost-effective sewerage treatment, and

(ii) Commission additional studies to analyse socio-economic options (such as willingness to pay/ ability to pay for different services in different locations) beyond those considered in the 2002 water study.

In summary, the biggest challenge will be for national and local governments to craft policies and rules within China's complex cultural and legal administrative system that provide incentives for users to increase efficiency of water use, and for polluters to clean up the water they use and return clean water to stream flows. Using a standard public economics framework, water requirements for public goods - such as ecosystem needs should be set aside first, before allocating property rights in water (to enable water markets to function and generate efficient allocation signals $\mathrm{s}^{70}$ ). Even then, water markets will have to be regulated to ensure public goods, such as public health, are not compromised. Until water markets are implemented, staying the course on increasing water and wastewater prices administratively and encouraging water conservation are necessary to reduce the wasting of current scarce water resources, as well as the new water supplies to be provided in the future.

\footnotetext{
${ }^{70}$ The new South African Water Act of 1997 considers its Water Resources as a public good, a resource for all, under state control and licensed, whereas in the past water in rivers, groundwater or captured was considered a private good, owned by the landowner. http://www.thewaterpage.com/SolanesDublin.html , The water laws in China have been revised recently to address the public goods issues raised above. (Xiangyang 2004).
} 


\section{References:}

Agricultural Outlook. 2000. "Water Pressure in China: Growth Strains Resources," January-February 2000.

Anderson, Kym. 2002. "Long run Impact of China’s WTO Accession on Farm Non-farm Income Inequality and Rural Poverty,” Washington DC.

Dinar, Ariel. 2004. "Pricing Irrigation Water: Principles and Cases from Developing Countries,” Resources for the Future.

Economy, Elizabeth. 2004. “The River Runs Black,” Cornell University Press.

Energy Information Administration (EAI) 2003. "Country Analysis Briefs” http://www.eia.doe.gov/emeu/cabs/chinaenv.html

Engelman, Robert and Pamela LeRoy. 1993. "Population and the Future of Renewable Water Supplies," National Council for Science and Environment.

Ernesto Zedillo, “On China’s Rise,” Forbes, May 24, 2004.

Fan, Cindy. 2004. "Migration in China: A Review of Recent Findings and Policy Recommendations," prepared for the 11th Five Year Plan of China.

Farugi, Naser. 2002. "Water Crises in China and Pakistan,” Woodrow Wilson International Center for Scholars (WWI).

Food and Agricultural Organization. (FAO) “AQUASTAT” (World Resources Institute) http://www.fao.org/ag/AGL/aglw/aquastat/main/index.stm

Genesis Technology Group. 2003. "The Water Crisis in China.”

Gunaratnam, Daniel. 2004. “China Water Resources Issues and Strategy.” Washington DC.

Huang, Jikum 2002. “The Nature of Distortion to Agricultural Incentives in China and Implications of WTO Accession” Washington DC..

Holland, Lorien 2000. “Running Dry,” Far Eastern Economic Review .

Japan Bank for International Cooperation 2004. Research Paper No. 28 March.

Ministry of Water Resources (MWR). 2002. "China Country Report on Sustainable Development - Water Resources"

Mulcahy, Patrick. 2003. "Finance and Legal Developments of Environmentally Friendly Wastewater \& Pollution,” The Sinosphere Journal Vol. 6 Issue 2 November 2003. 
Qian, Zhengying. 1994. "Water Resources Development in China,” China Water and Power Press.

Ravallion, Martin. 2004. “China’s Progress Against Poverty,” Washington DC.

Singer, R., 1999. The Philadelphia Inquirer, February 1.

University of British Columbia. “ Introduction to Beijing-Tianjin,” Center for Human

Settlement, University of British Columbia.

USDA. 2000. “Agricultural Outlook January - February 2000,” Economic Research Service.

Wang, Hua and Somik Lall. 2002. “Valuing water for Chinese Industries,” Applied Economics.

Wang, Hua. 2004. “China Water Issues,” Internal Note. Washington DC.

World Bank. 1992. “World Development Report 1992,” Washington DC.

World Bank. 1997. “Clear Water, Blue Skies,” September. Washington DC.

World Bank. 2001a. “Agenda for Water Sector Strategy for North China,” April.

Washington DC.

World Bank. 2001b. "China Air, Land, and Water Environment Priorities for a New Millennium,” Washington DC.

World Bank. 2002a. “World Development Report (WDR) 2003,” Washington DC.

World Bank. 2002b. “China Agenda for Water Sector Strategy for North China: Summary Report,” Washington, DC.

World Bank, 2003a. “China: Water Resource s Assistance Strategy.” Washington DC.

World Bank 2003b. “World Development Indicator (WDI)” Washington DC

World Bank, 2004. “11th Plan Water Note” (Internal Document edited by Douglas Olson.) Washington DC.

World Resources Institute (WRI). 2001. “World Resources 2000-2001” Washington DC.

WWI. 2004. "Water Conflict Resolution in China,” Washington DC.

Yusuf, Shahid and Kaoru Nabeshima. forthcoming 2006. "China's Development Priorities” Washington, DC: World Bank. 
Xiangyang, Xiong 2004. "The Revision of Water Law of P.R.C. and the Efforts for Remedying the Dry-up Problems of Yellow River,” The Ministry of Water Resources of P.R. C. http://www.wrrc.dpri.kyoto-u.ac.jp/ aphw/APHW2004/proceedings/JSE/56-JSE-A524/56-JSEA524.pdf

Xie, Ranhao, “China’s Current Water Shortage,” Beijing Time, Thursday, June 3, 2004.

Yaozhou, Zhou and Wei Bingcai. 2000. “Pricing Irrigation Water in China,” Pricing Irrigation Water, Yacov Tsur ed. Washington DC. Resources for the Future.

yedwards

C:IDOCUME 1 1yedwards\LOCALS 1\Temp\notesB5B01E\Zmarak Shalizi Addressing China's Growing Water Strateges.doc 04/17/2006 10:52:00 AM 